\title{
Mitigating Suburban English Writing Teachers' Constrained Professional Development Through Distance Education: One Case Study
}

Xiaodong Zhang

Beijing Foreign Studies University

\begin{abstract}
This study reports on how a Chinese suburban English writing teacher responded to systemic functional linguistics (SFL)-based distance education. The study draws on qualitative content analyses of the teacher's reflections, interviews, and classroom interactions. The results show that through SFL-based distance education, the teacher, interacting with his agency, overcame multiple constraints and developed academically in terms of how to understand valued academic writing. Additionally, the teacher also harnessed this newfound knowledge to support students' socialization into academic English discourse. The study concludes the effectiveness of SFL-based distance education for English writing teachers in similarly constrained contexts, which could be enhanced by teachers' agency. Implications of the study include synergizing the SFL-based curriculum with distance teacher education so that language educators can better assist students in gaining the knowledge needed for navigating academic English literacy.
\end{abstract}

Keywords: distance education, constrained context, English writing instruction, agency, systemic functional linguistics 


\section{Introduction}

Because of uneven economic distribution and limited transportation, in-service teachers in suburban/rural areas often face more difficulties gaining access to equitable resources than those in urban or developed areas (McConnell et al., 2013). In English writing classrooms in particular, due to a lack of effective teacher education, teachers often teach vocabulary or sentential accuracy, failing to unveil the complexity of English writing at both the level of content and language features (Schleppegrell, 2016). Additionally, distant education for language teachers typically only offers them a global perspective on teaching (i.e., how these programs should be implemented and what guidelines should be in place; Shin \& Kang, 2017), failing to help them understand what specific language resources underpin a text's content (i.e., meaning-making knowledge) and how to efficiently help students deconstruct or reproduce school texts (Harman, 2018).

On the other hand, teachers themselves (i.e., their agency) have been identified as a crucial factor in assisting in their own professional development (Beach, 2017). That is, teachers, based on their existing or past teaching and learning experiences, discover issues related to their current teaching context, finding solutions and resolving challenges (Smith, 2017). However, most teachers fail to rely on themselves because of the complexity of self as a power source (Beach, 2017). Indeed, teachers' self-based development follows a trajectory of joint learning from an expert before their independent decision-making emerges (e.g., complex terms from a teaching and learning theory might need experts' clarification; Mushayikwa \& Lubben, 2009). The optimal learning context thus would be the one where mediation occurs between an expert and teacher trainees, with the expert giving certain guidance while also providing space for teacher trainees' agency to grow (Liu \& Kleinsasser, 2015; Smith, 2017). Unfortunately, teachers' agency is underexplored in the field of distance education, which results in teachers' continued struggle with their own teaching when exiting distance education.

In sum, given the need for more accessible writing teaching knowledge among language teachers in underdeveloped areas, and the importance of maximizing their own agency, it is imperative that more research be devoted to language teachers' experiences in distance education. To address this gap in the literature, this paper investigates what language teachers can gain from a distance education curriculum that includes content/language-based writing instruction and a focus on teachers' agency.

\section{Literature Review}

\section{Distance Education for English Language Teachers}

In the field of English language teaching, including English as a foreign language (EFL) or English as a second language (ESL), research about distance education for EFL/ESL teachers is still limited (Knox, 2017). In particular, among the few studies in the field on English language teaching, Shin (2017) showed that pre-service English teachers in the United States were able to gain increased awareness of interaction with each other through on-line platforms. Similarly, Liu and Kleinsasser's (2012) study showed that EFL teachers in Taiwan, through on-line based professional development, had positive experiences in sharing ideas, resources, and constructing knowledge in relation to their teaching. However, while these previous studies on distance education for English language teachers, similarly 
to other fields, such as science (McConnell, et al., 2012), demonstrated the power of distance education in overcoming geographical constraints, they were limited to providing teachers with general teaching methodologies (e.g., Liu \& Kleinsasser, 2012). As such, Hall and Knox (2009) argued for innovative distance education that can allow language teachers to conduct "theoretically grounded discourse analysis of materials" (p. 77). As Schleppegrell (2016) also noted, "teachers now need new ways of incorporating a focus on language in the content classroom so that they teach language and content simultaneously" (p. 116). That is, to better facilitate distance teacher education for language teachers, it is necessary to guide them in gaining a more micro understanding of English language literacy at the level of both language and content.

\section{Teachers' Agency}

Teachers' agency is defined as "the power of teachers (both individually and collectively) to actively and purposefully direct their own working lives within structurally determined limits" (Hilferty, 2008, p. 167) and is "motivated by teachers' sense of responsibility toward their students and their academic wellbeing" (Phan \& Hamid, 2017, p. 40). What this definition suggests is that teachers' agency is also important because it offers an interface for teachers to tailor their instruction to their own local classroom (Smith, 2017). That is, they can make their own efforts to reflect on their past and present teaching experiences and use those reflections to make changes to their ongoing practices.

While abundant research has highlighted teachers' agency in establishing their efficacy in traditional classrooms (e.g., Phan \& Hamid, 2017), surprisingly little attention has been cast on how distance teacher education supports (or does not) teachers' agency on their journey of knowledge internalization. One marginally relevant study was conducted by Mushayikwa and Lubben (2009), in which science and mathematics teachers from high schools were first trained and then encouraged to rely on themselves in terms of how to use internet resources. The result of this study showed that teachers became more confident through self-exploration and better at enhancing their classroom teaching (e.g., teachers' flexible use of multiple teaching methods in fostering students' critical thinking). As Mushayikwa and Lubben (2009) further noted, "maximizing the self-direction drive... ensures that beneficiaries take ownership of the programmes and help in sustaining them" (p. 382). In other words, the interaction between teachers' agency and their ongoing practices serves as a catalyst in helping them internalize knowledge or innovate curriculum when exiting teacher education programs. Given the importance of both distance education and teachers' agency, it is therefore imperative to investigate how the two factors impact language teachers' professional development.

\section{SFL-Based Distance Education}

The applicability of Halliday and Matthiessen's (2014), Systemic Functional Linguistics (SFL) in teacher education is particularly marked by its trinocular illustration on the relationship between context, meaning (i.e., content), and the linguistic features (grammar/vocabulary) of a particular text or stretch of discourse, and is thus helpful in addressing the complexity of English academic literacy in the classroom (Schleppegrell, 2016). In particular, SFL primarily uses the following constructs to unveil the myth of language activities: genre, context of situation, three meta-meanings, and lexicon/grammar. Genre (the type and sequence of communicative activities) regulates language 
activities in a larger cultural context. For example, in expository writing, the discourse may unfold itself from an introduction into body paragraphs and a conclusion (Schleppegrell, 2016). Within the matrix of genre, SFL further employs the construct of register variables to show how discourse meaning is constructed (writing texts) or deconstructed (reading texts). The three variables are field (what is going on), tenor (the relationship between discourse participants and their evaluative stances), and mode (the channel of communication). These variables are semantically related to the three meanings respectively constructing/revealing the content of discourse: Ideational meaning (language users' experience of the world), interpersonal meaning (the way of interacting with discourse participants as well as their evaluative stances to the subject matter), and textual meaning (the way of organizing information).

SFL also provides its own categories for showing how the three dimensions of meanings in texts are labeled and understood (Halliday \& Matthiessen, 2014). For example, participants (noun phrases) and process (verbs) show that inanimate subjects are preferred in academic writing (e.g., nominalization). The labels provided by appraisal system, on the other hand, includes attitude (language options that project language users' attitude), graduation (language options that intensify or weaken discourse), and engagement (language options that show the source or certainty of information). Additionally, cohesive ties (e.g., transitional words) and theme patterns (e.g., the repetition of the beginning parts of adjacent sentences) explain how discourse is coherently combined. Indeed, all these constructs from SFL illuminate the complexity of academic English writing in an accessible way by providing teachers with knowledge of written discourse at the level of both meaning and linguistic resources.

The advantages of SFL as an instructional tool, as illustrated above, have been widely documented in traditional face-to-face teacher preparation programs, especially for secondary level English teachers in the United States (Harman, 2018). For instance, Huang, Berg, Siegrist, and Damsri (2017) showed that, through exposure to the tenets of SFL, secondary mathematic teachers in a U.S. school were able to conduct discourse analysis and help students write appropriate answers to questions (e.g., students' use of conjunction words, or the use of mathematic terms instead of everyday language). In the field of language teaching, Gebhard, Chen, Graham, and Gunawan's (2013) SFL-based education of pre-service and in-service English teachers who were enrolled in a Master's program in the United States illustrated that these teachers (including those from an EFL context) were able to understand writing and reading as a meaning-making process and demonstrate interactions between meaning and linguistic resources in their own texts (e.g., projecting objective tone through nominalization or inanimate subjects). Despite the power of SFL in assisting language teachers' development as shown in these studies, limited research has highlighted the challenges of teaching/learning SFL in the language classroom (Zhang, 2018), with the relevant previous studies focusing on teachers' academic performance following training (e.g., Huang et al, 2017). In addition, there is almost no such research in the field of distance teacher education for teachers in constrained contexts.

In sum, given the three lines of literature above, there exists a crucial research gap: while distance education is a venue for engaging suburban/rural teachers in equitable professional education, there is a lack of empirical research in the context of English language teaching, let alone how to best guide teachers in overcoming challenges of learning through a new curriculum, understanding the complexity of academic English writing, and fostering their agency in their own classroom. To fill this 
research gap, this current case study, with a focus on a suburban English teacher from a constrained educational context in China, explores the following research question: How does the teacher (1) develop himself through SFL-based distance education and (2) conduct follow-up writing instruction on his own?

\section{Methodology}

A qualitative case study approach is useful and convenient for unearthing the complexity of a phenomenon in a particular context (Yin, 2014). Given that this study attempts to show how teachers in the EFL context where teaching was limited to language accuracy responded to SFL-based distance education, a qualitative case study approach is an optimal fit for this project.

\section{Research Context}

The focus of this one-year study was derived from a larger project on language teachers' agency, teacher education, and classroom teaching. Because there have been few efforts to offer SFL-based distanced education for EFL teachers, let alone in China, I initiated this project by connecting with teachers in suburban universities in China who could not access effective professional development opportunities because of traveling or finance constraints. I invited teachers, known directly or indirectly, from suburban universities to participate in this year-long SFL-informed project. Seven of those teachers voluntarily chose to participate.

The SFL-based distance teacher education occurred in two phases corresponding to each academic semester. In the first phase of this project, which took place during the first six months of the academic year, the education included teachers' self-learning of SFL-based materials assigned by me, followed by my mediation (primarily in Chinese) of their reading via a chatting tool called Wechat (Wechat is a mobile application used widely in China where teachers and I can talk audio-visually and share materials with one another). The online weekly meeting lasted about one hour and ten minutes; the meeting for each teacher was on an individual basis and depended largely on their availability (e.g., the focal teacher in this study had his meeting time scheduled on Thursdays from 8:0opm-9:30pm). The learning materials used during this study corresponded to each of the main constructs of SFL. These reading materials (e.g., academic papers, audio-visual resources) were selected online based on the accessibility of their content relevant to the background of each teacher in particular (e.g., Schleppegrell, 2016; see also Zhang, 2018).

In the second phase of the project (i.e., the second semester), teachers were encouraged to use their newly gained knowledge, if any, in their own classroom. During this process, I did not provide any intervention measures. Instead, I only read and analyzed teachers' recordings to see how, if at all, particular teaching activities related to SFL were used. If the teachers expressed any confusion, I would send materials to them and ask them to explore the needed information.

\section{Participants}

John (a pseudonym) was selected as the focal participant in this study because he was able to share 
his audio-recordings with me, as well as his students' writing samples. In addition, John taught expository writing, a primary focus of this current study. Most importantly, John's teaching knowledge about the English language, like the majority of EFL teachers in China and other contexts, was limited to rule-based grammar (Zhang, 2017), which made him an interesting case to explore given the differences between that approach and this SFL-informed one.

John was born and raised in China. He had been an English teacher in a third-tier suburban college in China for about five years prior to his enrollment in this study. With a Master's degree in English literature, John's primary job was teaching expository writing to college students on a weekly basis, and was focused on skills-based writing, such as sentence-level grammar. Being unsatisfied with this approach and accepting the status quo, John wanted to better himself-and did so by joining this project.

\section{Data Collection and Analysis}

Data collection and analysis was a simultaneous process (Marshall \& Rossman, 2014), informed by a qualitative case study approach as well as a SFL multilayered perspective on writing as a meaning-making process (Schleppegrell, 2016). To answer the first part of the research question-how John developed himself through SFL-based distance education-reflective journals (in John's first language, Chinese) based on John's independent reading prior to each training session, were collected. Reflections included his thoughts on the reading materials. Altogether, 23 reflections were collected. In addition, reflective journals were sent to me two days before each training session, and based on the reflective journals, semi-structured interviews were conducted before and after each training session. The language spoken during the interviews was Chinese, John's first language, so as to maximally elicit his response to the SFL-based distance education, and, at the same time, also to clarify some confusion in his reflective journals. To answer the second part of the research question-how John relied on himself in his follow-up teaching-evidence of John's teaching practices was collected during the second semester. That data, however, was provided by John himself, and also collected by him. In particular, the data included recordings of three classroom units, which ranged from 90 to 125 minutes each. At the same time, following the listening of these audio-recordings, follow-up interviews for clarification purposes were also conducted.

Data analysis was primarily inductively conducted through content analysis by the researcher of this project (Marshall \& Rossman, 2014). In particular, to ensure the trustworthiness of the analysis, a constant comparison and condensation within datasets (among interviews, reflections, and in-class teaching) was conducted (Marshall \& Rossman, 2014). That is, each of the transcribed texts was read many times until initial codes were identified (e.g., teachers' constraints). Later on, these codes were combined to yield themes. Notably, although in the final report of this study the English version of interview excerpts (IE), reflection excerpts (RE), and John and his students' interaction were presented, the initial data analysis was transcribed and analyzed in Chinese, the language used in the interviews, reflections, and in John's classroom. Meanwhile, the research question and previous studies (e.g., Beach, 2017) were also examined in order to facilitate analysis. To further ensure internal validity, themes generalized from the dataset were reviewed by a research assistant and two experts on SFL-based teacher education, all of whom approved the analysis. In addition, when the 
paper was completed, I also sent it to John, who read and agreed with the reported findings in this current study.

\section{Findings}

\section{Finding 1: John's Tortuous Development Through Exposure to SFL-based Education}

In the first half of the semester of SFL-based distance education, John learned the importance of SFL's perspective on writing and displayed an enhanced awareness of agency in learning new knowledge. Nevertheless, John's development interacted with diverse factors, such as his prior education and the external mediation from the researcher.

\section{John's Initial Attitude Toward SFL-Based Education: Interesting Yet Realistic}

At the beginning of the project, John was pleased with the SFL-based distance teacher education he was about to be immersed in. He reflected, "The distance education seems a good choice to me.... I really do not have time and money to travel so far, and I have my family to take care of" (RE1); and "SFL's perspective on writing seems interesting and might be useful.... Its instructional focus is on both language and content instruction, [which] I have never had before" (IE1). As shown in these two excerpts, the SFL-based distance education looked promising to the suburban teacher who wanted to improve himself but found it challenging because he had time and financial constraints.

John's enthusiasm for SFL-based teaching instruction was particularly propelled by his determination to be a better teacher who could help his students academically: "They cannot write well... but they have to prepare all kinds of academic writing, for their future study. I worry because I am an English teacher... it is my responsibility to train them well" (RE2); and "I have tried...you know...they cannot even have correct sentences...and they cannot write coherently... except teaching grammar, what else can I do?" (IE2). In other words, in observing the difficulties his students faced and weighing that against what he perceived to be a lack of effective methodology, John was motivated to join this distance education program with the hope of better preparing his students for academic success.

However, John was also realistic about distance education, with the expectation that no course would be perfect and be used directly without the teachers' own efforts in making adaptations: "I am not sure everything I learn will be useful.... Classroom teaching is different...and it cannot teach everything. Teachers have to do some part by themselves" (RE3); and

I did some on-line learning...(and) it seemed vague to me, such as genre-based teaching.... It has no dialogue with me.... It is very short...and I do not understand [the content].... These experiences taught me a [positive] attitude toward distance education. (IE3)

Despite the fact that John was willing and ready to embrace SFL-based distance education, he was aware that he would need to make additional efforts on his own to implement SFL and integrate it into his own curriculum following training. John's realistic attitude toward distance education emerged from his previous negative experiences with non-traditional classroom learning (i.e., online learning). 


\section{Increased Alignment and Refreshed Conceptualization as a Result of Mediation and Teachers' Agency}

John's professional background coupled with the time he had to digest the SFL-based reading materials also created challenges for him. As John reflected, "I had never learned linguistics, so it took much time for me to understand sometimes... although the materials were carefully selected" [RE4]. In the interview he further added, "I am optimistic, but in the process, I had times of doubting what I was learning: could I really understand most of the content in the reading materials on my own?" [IE4]. Despite his investment in the distance education program, John's experience was mixed because of how his prior knowledge and background were interacting with the new materials.

Unsurprisingly, there was a time in which John complained about the effectiveness and suitability of SFL and the reading materials because of their complexity: "It [the construct of appraisal system] was so complex; my students are not that advanced.... They might feel more challenged.... (and if) I were to make them [fail]...my department would also blame me" [IE5]; and "I just periodically feel a construct is getting complex. I am not sure whether that is my illusion... or because it is hard to grasp the theory" [RE5].

Thus, with increasing information from the distance education program, John sometimes felt overwhelmed or doubtful because he perceived a mismatch between his students' level of writing and the seemingly complex and dense processes that the SFL-based readings called for. John's anxiety was mitigated, however, with the triadic interaction among his increased knowledge, agency, and external mediation, which helped him to achieve a balanced perspective on knowledge appropriation. John explains that "I know at this time I cannot apply the knowledge to my own classroom teaching...but I will...because I understand the importance of what this education can do, like how I am scaffolded to understand SFL during on-line meetings" [IE6]; and

I often rush. I realize it is not good...knowledge and the whole system of a theory takes time to understand.... In the past month, when I have settled down I have found everything becomes clearer to me. Also, you[the researcher] helped me and encouraged me to face up to the complexity of theory... all we need to do is to patiently understand it...by myself and with assistance"[RE6].

In other words, he realized that the initial bumpy road of learning was a result of his own desire to quickly understand the materials, which caused him to underestimate the complexity of a language theory. These challenges were obviously diluted in the latter phase of the project as a result of the interaction between John's agency and the external mediation by the researcher.

Indeed, unlike his previous experiences with on-line resources and instruction, John gradually experienced the benefits of SFL-based distance education because of his galvanized agency and external mediation. As he said, "The reading materials were really arranged in a gradual way, so following this, I can really figure out the most content of on-line resources by myself... I feel a sense of achievement" [IE7]; and "Any learner has to rely on themselves ultimately....In the process of mediation, I feel the teacher is really prompting me to think. I feel more confident to continue to rely on myself" [RE7]. As evidenced by these excerpts, John's consciousness of agency (i.e., his reliance on 
himself) was further enhanced in a context where mediation from the researcher was provided through multimodal channels. As such, John felt more aligned with SFL's perspective on language learning.

Most importantly, John's conceptualization of distance teacher education was also gradually reformed as he realized that there was not a need to be a thorough theoretical linguist, but instead a good-enough applied linguist. As John shared, "I felt I also shed my stubborn beliefs about thoroughly understanding everything before application.... To be an educator, we could draw on parts of theories or the most important tenets" [RE8]; and "I mistakenly thought that only when we know everything of a theory can we apply it, which seemed impossible for an educator... Instead, we can learn by action and use what we already know" [IE8]. That is, John formed a more flexible stance toward the teacher education program; his constant battle with his prior teaching methodologies, the mediated instruction, and an increase in his self-efficacy all helped shape him into a confident teacher and good-enough curriculum innovator.

\section{Emerging Meta-Linguistic Awareness and Agentive Attempts in Curriculum Design}

The SFL-based constructs of register, the three meta-meanings, genre, and the related linguistic features, ultimately catalyzed John's re-conceptualization of writing to primarily as a meaning-making process. As John reflected, "While I have not applied SFL-based constructs to my classroom, it really promotes my thinking of writing not just at the sentence level, but also at the meaning-making level" [RE9]. Yet, because of the students' level at John's university, he also had a peripheral belief about the importance of teaching sentential grammar to his students. As John emphasized,

For me, I have realized how both content and language are important, especially how to make students write meaningfully, but I feel it would be unrealistic to ignore students' basic language skills in my university. They also need grammar teaching. (IE 9)

In other words, John constructed a mixed meta-linguistic understanding about language learning and writing instruction, with meaning-making beliefs as the predominant factor. John's determination to transform himself into a meaning-making based writing instructor was particularly illustrated by his final reflections on the SFL-related constructs and his planning of the curriculum (Table 1 below).

Table 1

Johns' Understanding of SFL-Based Constructs and Relevant Curriculum Planning

\begin{tabular}{|l|l|}
\hline Genre-based reflection & $\begin{array}{l}\text { John's reflections: I had contact with genre before but did } \\
\text { not know too much. It turned to be a semantic and a matrix } \\
\text { concept that not just includes the structure of texts and social } \\
\text { purposes but also linguistic features (e.g., the concise structure } \\
\text { feature in writing). } \\
\text { John's curriculum design: For this construct, I would let } \\
\text { students know the following: }\end{array}$ \\
\hline
\end{tabular}




\begin{tabular}{|c|c|}
\hline & $\begin{array}{l}\text { 1. Know the purpose of different genres (e.g., expository, } \\
\text { argumentative). } \\
\text { 2. Know the linguistic features specific to different genres. }\end{array}$ \\
\hline Register-based reflection & $\begin{array}{l}\text { John's reflections: I used to know the difference between } \\
\text { spoken English and written English. But I did not know why. } \\
\text { Now, with the three variables, I understand why English } \\
\text { writing has its unique features (such as its tone or its text } \\
\text { flow). } \\
\text { John's curriculum design: I will teach the three variables } \\
\text { in a plain language (presumably students' first } \\
\text { language-Chinese). } \\
\text { 1. Field: Remind student of events (or topics) they are } \\
\quad \text { writing about. I have noticed my past students wandered } \\
\text { off topic. } \\
\text { 2. Tenor: Foster my students' reader-centered awareness, } \\
\text { instead of focusing on grammatical accuracy. } \\
\text { 3. Mode: Remind my students that our writing should be } \\
\text { logically tightened, not as loose as spoken English. }\end{array}$ \\
\hline $\begin{array}{l}\text { Meanings and linguistic } \\
\text { features }\end{array}$ & $\begin{array}{l}\text { Johns' reflections: I used to focus on the accuracy of } \\
\text { grammar or advanced vocabulary. I have ignored the } \\
\text { interrelated relationship between lexicon/grammar and } \\
\text { content (ideational meaning, interpersonal meaning, and } \\
\text { textual meaning). In my future writing instruction, while I } \\
\text { would help students focus on some traditional grammar } \\
\text { knowledge (e.g., tense, run-on sentences), I will try my best to } \\
\text { focus on how to connect grammar with content. } \\
\text { John's curriculum design for the two constructs: I will } \\
\text { teach the following elements: } \\
\text { 1. Teach students that correct sentential grammar is not } \\
\text { enough. } \\
\text { 2. Use sample texts to highlight particular linguistic } \\
\text { features specific to a genre (e.g., the teaching of } \\
\text { impersonal tone in expository writing; the teaching of } \\
\text { engagement resources to show credibility of information; } \\
\text { the teaching of cohesive or thematic patterns in the text). }\end{array}$ \\
\hline
\end{tabular}


In other words, John's refreshed knowledge by the end of the first six months and his attempts in making his new writing curriculum informed by SFL-based constructs jointly illustrated his transformation due to the SFL-based distance education.

\section{Finding 2: John's Further Exemplification of His Agentive Role in the Classroom}

John's transformation was more saliently demonstrated by his agency in using the constructs of SFL when analyzing his students' work and mediating their understanding of writing in the second semester. Typically, John emphasized the importance of context before he delved into how to use contextually appropriate linguistic choices in making meanings in different types of writing. As shown in the following subsections, in the process, John typically showed students' writing excerpts to the whole class and guided students' re-conceptualization of writing, though he would also emphasize mechanical errors if he found them. In addition, John would use students' first language (albeit for the reader's convenience the translated English version is presented below) and understandable language (although many terms exist in SFL) in the classroom.

\section{Interpersonal Meaning and John's Agentive Attempt}

One vignette of Johns' agency in unpacking interpersonal meaning with students was exemplified by his instruction on how to soften tone in academic writing through his knowledge of the SFL-based appraisal system (i.e., engagement). In the dialogue below, John used one student's writing excerpt as an example. In relation to this excerpt, John and his students had the following interaction:

John: The tone of statements has to be carefully projected in your writing. Think about Chinese [students' first language]....you use modal verbs, right? [The student's written sentence John was talking about: "Children imitate what they have seen on the internet, which is dangerous."]

Students: But we are not conscious of this in Chinese.

John: That is the thing. I was not aware of that, either. In English, we have also to know the importance of modulating your tone. All information you present is based on the strength of evidence or fact available [John re-showed the student's sentence]. Is the tone too assertive? Do you think it is event that must happen?

Students: (After engaging in discussion with each other) No.

John: How can we make ourselves more convincible? Think about some modal verbs and adverbs or other words that can soften our tone?

Students: (Some students) Add “may" before "watch"... add "likely" before "dangerous."

John: Great choices in this context. [Following his acknowledgement of the students' answer, John showed his version: "Children tend to imitate what they have seen and heard on the internet, which is sometimes dangerous."] 
As illustrated above, John demonstrated his efforts in implementing his SFL-based knowledge about interpersonal meaning, which he acquired from the distance education. In particular, John highlighted the importance of engagement (certainty of statements) in projecting information. To further students' understanding of this dimension of interpersonal meaning, John also highlighted the linguistic repertoire students needed to use, such as sometimes and tend to. Johns' efforts in teaching this piece illuminated how he actively engaged in linking his knowledge with his current practices, and how he solved the problem his students were facing and helped them express a particular voice/tone in their academic writing.

\section{John's Instruction of Ideational Meaning in His Classroom}

John also emphasized how the contextual variable-field interacted with writing expectations. This interaction, like the one above, was also based on students' writing excerpts. The excerpt in this section, however, is from students' expository writing on the benefits of banning smoking on campus.

John: Following the topic sentence, what do we do for the rest of paragraph? [The student' writing work John referred to: "Banning smoking on campus has many advantages. In the first place, it prevents non-smokers from being exposed to polluted air. I think this is important."]

Students: Elaborate on the claim.

John: Yes. That is the activities you are supposed to do. See... you are providing facts or evidence...not your personal opinions... Look at the phrases here "I think." What does this prove? You should present information. But what is "I think" associated with?

One student: Too subjective (with other students nodding).

John: Words showing personal mental state should be avoided here... this is your personal projection. Here you are providing information... like you are writing facts... so avoid personal evaluation here.

John: How about this conclusion part? We have learned that English prefers explicit logical relationships. But how is this one? [The student work: "Smoking may help some people relax. Restricting smoking on campus is imperative in that it gives off pollutants, affects non-smokers, and harms their own health.”]

Students: Looks good... no grammar mistakes.

John: But is the logical relationship clear between the first two sentences? The author is making a concession here.

One student: We can add "although" at the beginning of the first sentence.

John: (Acknowledged the answer and provided a sample: "While smoking may help some smokers release pressure, restricting smoking on campus is imperative in that it gives off pollutants, affects non-smokers, and harms their own health."] 
In the above dialogue, John was demonstrating his knowledge of ideational meaning from SFL. Indeed, he was emphasizing how academic writers' experiences can be projected in a cultural and linguistically acceptable way. In doing so, John illustrated and emphasized the importance of avoiding inappropriate processes (e.g., personal mental process) in order to meet the generic purpose of expository writing, which is to present information. In addition, within the context of ideational meaning, John also helped students notice the importance of logical meaning in terms of using explicit linguistic signs in projecting reasoning. It was thus becoming apparent at this point that John's adapted teaching strategies were a result of both the SFL-based distance education and also his own investment in improving his language teaching.

\section{John's Scaffolding of Textual Meaning}

In this dimension, John tried to help students challenge themselves, moving their attention from individual sentences to the flow of semantic groups, which includes several sentences together. The writing topic was comparing and contrasting boarding school and a day school for high school students. John and his students had the following dialogue:

John: There is a grammar mistake here... where? [One student wrote: "Staying on campus might not be healthy for high school students' growth. Many are still young. Parents worry about them. Students may also easily (be) influenced by other bad ones."]

Students: (pause for a few minutes) should "be influenced."

John: Yes....Except that, do you think the information is jumpy? I mean the first two sentences.

Students: (silence) We do not understand.

John: You are talking about young students.... Suddenly, you talk about parents.... That is a surprise. Try to use the same topic phrases..."they," (or) "these young students." Let's do it together.

Students: They may not be able to.

John: [John followed his students' answer and said] deal with their life on their own.

John: Nice... you see, when you maintain the same topic phrases, your idea won't be disrupted. Now look at another sentence... it is a new supporting idea... so show readers the signals... remember transitional words you have learned.

Students: Oh...we can say... in addition, or additionally.

John: [Acknowledged students' answer] John pulled out his version: "Staying on campus might not be healthy for high school students' growth. First, many are still young, and they may have difficulty dealing with their life on their own. In addition, they may be easily influenced by bad students." 
The above interaction displays John's effort in showing the importance of writing at the discourse level, not limited to individual sentences, such as grammar mistakes. John's practices particularly illustrated his agentive role in assisting his students in becoming aware of the constant thematic resources (e.g., many, they) in connecting interrelated semantic groups. In addition, within two semantic groups, John also highlighted the use of a cohesive devise (e.g., in addition) in scaffolding students for understanding and writing coherent writing at the discourse level. In all, John integrated his SFL-based education and agency in applying the relevant knowledge to his teaching, supporting his students' extension of writing knowledge from individual sentences to the textual level.

\section{Discussion}

This case study on providing SFL-based distance education to language teachers in constrained contexts has two important findings. First, the teacher was able to benefit from this SFL-based distance education, conceptualizing language teaching as a meaning-making process, although the path of his knowledge appropriation was bumpy. That is, the interaction between both facilitating factors (e.g., his agency) and constraining factors (e.g., his prior professional development) propelled John to renegotiate his own teaching practices. More importantly, during this education, John's agency was further galvanized by the trainer (the researcher of the project), assisting him as he bravely waded through tough moments and flexibly invested himself in redesigning his writing curriculum (i.e., SFL-based curriculum). The finding buttresses the previous research that distance education is an effective way for teachers to break away from the constraints of time, geography, limited in-service education, and funding for traveling (e.g., Knox, 2017).

Second, this study, among few other empirical studies (c.f., Mushayikwa \& Lubben, 2009), further verified the importance of highlighting the mediation that happens between distance education trainers and teacher trainees. It empirically illuminates that in a constrained context, teachers could independently improve their teaching once their own agency was activated through external mediation, as illustrated by John's appropriation of instructional content and his willingness to challenge his prior teaching style and implement SFL-based curriculum.

Third, the study shows that SFL can have a positive impact on teachers' conceptualization and their practices. While previous studies have illustrated the impact of SFL on teacher education, they were limited to the traditional classroom context where teachers received face-to-face instruction and improved their teaching skills (e.g., Huang et al, 2017). This study complements existing SFL-based teacher education studies and illustrates how, in a non-traditional context (i.e., distance education), SFL praxis can help change teachers' perceptions and practices while also showcasing accompanying challenges encountered by the teacher. In addition, this current study offers an accessible SFL-based curriculum for distance education, supporting teachers' internalization of writing as a meaning-making process and complements existing distance education in the field of language education, where there is a lack of empirical studies on teachers' meta-linguistic knowledge (Knox, 2017).

\section{Conclusion and Implications}


While the findings of this research cannot be generalized, there are two important conclusions that those working in a similar context may find useful. First, SFL-based distance education seems to be an effective tool in helping teachers understand writing as a meaning-making process. Second, teachers' development is a result of the interaction between multiple factors such as self-determination of being a good teacher and external mediation from the distance education. Ultimately, teachers independently adapt their teaching, benefiting their students' socialization into authentic academic English writing communities.

Implications of this study include the following dimensions. One is that in many education contexts (e.g., underdeveloped areas), language teachers have limited access to effective teacher education and they struggle with how to teach genre-specific writing to students from different disciplines at different levels (e.g., mathematics, science; Huang et al., 2017; Schleppegrell, 2016). In response to the uneven and inequitable distribution of education and economical resources, SFL-based distance education, with its focus on both language and content, seems to be an optimal approach in assisting teachers in transcending the limitations of time or place. Additionally, given that distance teacher training programs are short, and teachers ultimately have to rely on themselves to gain new knowledge, this study suggests that teachers' agency should be effectively galvanized so that they can better regulate their teaching when exiting teacher programs. Finally, as a case study that was only focused on typical EFL teacher, findings should be carefully treated and can only be extended to similar contexts (Yin, 2014). Future studies could use a similar SFL-based approach and implement distance education for larger cohorts of teachers.

\section{Acknowledgements}

The study is funded by National Social Science Foundation of China (17CYYo19). 


\section{References}

Beach, P. (2017). Self-directed online learning: A theoretical model for understanding elementary teachers' online learning experiences. Teaching and Teacher Education, 61, 60-72. doi:10.1016/j.tate.2016.10.007

Gebhard, M., Chen, I. A., Graham, H., \& Gunawan, W. (2013). Teaching to mean, writing to mean: SFL, L2 literacy, and teacher education. Journal of Second Language Writing, 22(2), 107-124. doi: 10.1016/j.jslw.2013.03.005

Hall, D., \& Knox, J. (2009). Issues in the education of TESOL teachers by distance education. Distance Education, 30(1), 63-85. doi:10.1080/01587910902845964

Halliday, M. A. K., \& Matthiessen, C. M. (2014). An introduction to functional grammar. London: Routledge. doi: 10.4324/9780203431269

Harman, R. (2018). Bilingual learners and social equity: Critical approaches to systemic functional linguistics. New York: Springer. doi:10.1007/978-3-319-60953-9

Hilferty, F. (2008).Theorising teacher professionalism as an enacted discourse of power. British Journal of Sociology of Education, 29(2), 161-173. doi: 10.1080/01425690701837521

Huang, J., Berg, M., Siegrist, M., \& Damsri, C. (2017). Impact of a functional linguistic approach to teacher development on content area student writing. International Journal of Applied Linguistics, 27(2), 331-362. doi: 10.1111/ijal.12133

Knox, J. S. (2017). Participant perspectives and critical reflections on language teacher education by distance. Australian Journal of Teacher Education, 42(5), 66-86. doi:10.14221/ajte.2017v42n5.5

Liu, M. H., \& Kleinsasser, R. C. (2015). Exploring EFL teachers' CALL knowledge and competencies: In-service program perspectives. Language Learning \& Technology, 19(1), 119-138. Retrieved from http://llt.msu.edu/issues/february2015/liukleinsasser.pdf

McConnell, T. J., Parker, J. M., Eberhardt, J., Koehler, M. J., \& Lundeberg, M. A. (2013). Virtual professional learning communities: Teachers' perceptions of virtual versus face-to-face professional development. Journal of Science Education and Technology, 22(3), 267-277. doi:10.1007/s10956-012-9391-y

Mushayikwa, E., \& Lubben, F. (2009). Self-directed professional development-Hope for teachers working in deprived environments? Teaching and Teacher Education, 25(3), 375-382. doi: $10.1016 /$ j.tate.2008.12.003

Marshall, C., \& Rossman, G. B. (2014). Designing qualitative research. Thousand Oaks: Sage.

Phan, T. T. H., \& Hamid, M. O. (2017). Learner autonomy in foreign language policies in Vietnamese universities: an exploration of teacher agency from a sociocultural perspective. Current Issues in 
Language Planning, 18(1), 39-56. doi: 10.1080/14664208.2016.1201231

Schleppegrell, M. J. (2016). Content-based language teaching with functional grammar in the elementary school. Language Teaching, 49(1), 116-128. doi: 10.1017/s0261444814000093

Shin, D. S., \& Kang, H. S. (2017). Online language teacher education: Practices and possibilities. RELC Journal. doi: 10.1177/0033688217716535

Shin, D. (2017). Contextual factors of online teacher education in TESOL: An activity theory perspective. In J. Perren, K. Kelch, J. S. Byun, S. Cervantes, \& S. Safavi (Eds.), Applications of CALL theory in ESL and EFL environments (pp. 80-93). Hershey, Pennsylvania: IGI Global. doi:0.4018/978-1-5225-2933-0.choo5

Smith, K. (2017). Teachers as self-directed learners. Singapore: Springer. doi: 10.1007/978-981-10-3587-6

Yin, R. K. (2014). Case study research: Design and methods. Thousand Oaks, CA: Sage.

Zhang, X. (2017). Understanding Chinese EFL teachers' beliefs and practices in the textbook-based classroom. Bern: Peter Lang. doi: 10.3726/b11563

Zhang, X. (2018). Connecting OER with mandatory textbooks in an EFL classroom: A language theory-based material adoption. International Review of Research in Open and Distributed Learning, 19(2), 89-110. doi: 10.19173/irrodl.v19i2.3479

\section{Athabasca \\ University}

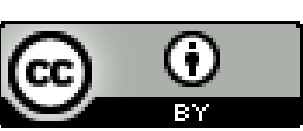

